\title{
INVESTIGATION OF THE RELATIONSHIP BETWEEN MUSEUMS AND CITIES IN THE CONTEXT OF IMAGE: CASES FROM ISTANBUL
}

\author{
Ilker Fatih OZORHON ${ }^{a}$, Guliz OZORHON ${ }^{b}$ \\ Faculty of Architecture and Design, Ozyegin University, Çekmeköy Campus \\ Nişantepe District, Orman Street, 34794 Çekmeköy, Turkey \\ E-mails: ${ }^{3}$ ilker.ozorhon@ozyegin.edu.tr (correspondingauthor); buliz.ozorhon@ozyegin.edu.tr
}

Received 03 March 2015; accepted 06 July 2015

\begin{abstract}
Whether created by transforming historic buildings, whether contemporary and new design products, museums play a key role in terms of the image and attractiveness of the city they are located in. This study investigates the relation that the museums in Istanbul have established with the city in the context of image. The method employed is to first introduce the theoretical context of the subject based on literature review; to analyze the selected museums in terms of the city-museum interaction and to evaluate the selected museums within the context of the contributions they make to the image of Istanbul by descriptive methodology. As a result, the contribution of the museums on the city and the contribution of the city on the museums have been demonstrated and the varying and symbiotic nature of this relationship has been emphasized.
\end{abstract}

Keywords: museum, city, image, Istanbul, architecture.

\section{Introduction}

As an important part of the social and cultural life, the museums are landmarks of the city. Due to their symbolic values for the entire city and their indispensable position in the cultural and artistic life of the city, museums are considered as culture temples of the centenary (Jencks 2005). It would not be misleading to state that New York Guggenheim Museum (Fig. 1) that is described by Foster (2004) as "today the museum performs its demonstration value more than anything, this is the main issue that attracts people and is worth of respect", is the first example that shows that the perception related to museum designs has changed. The Museum which the construction began in 1956 was one of the most important buildings of the period. The project designed by Frank Lloyd Wright has opened its doors in 1959 after a three-year period of construction. Introducing a new approach to museology by its iconic, sculptural structure; it has raised for the first time a debate of whether the physical structure precludes the function of the building or not.

Today's museum buildings are not considered as single-function buildings only for exhibition but on the contrary as multi-functional structures that offer and exhibit themselves as a value together with its contents.
Aalst and Boogaarts (2002) indicate that museums around the world are repositioning themselves and this repositioning process runs parallel to a change in the function of museums. The museum is becoming more and more a (temporary) exhibition space, whereby its other characteristic museum functions such as conservation and restoration of the collection and the pursuit of scholarly research are pushed into the background (Aalst, Boogaarts 2002).

On the other hand, museum is perceived as a building that shows a potential of urban landmark and

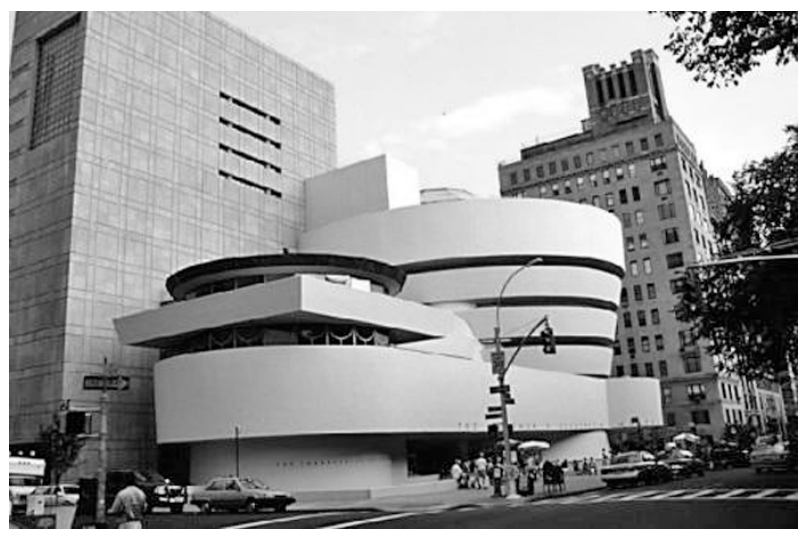

Fig. 1. New York Guggenheim Museum (www.bc.edu) 
owing to this potential it represents the city and has the power to transform the surroundings (Güzer 2010). According to Köksal, the museum has tried to play a transformative role in the city with its iconic value in the last 30-40 years and the first example of this is the Pompidou Centre (Fig. 2) in Paris (Gökmen 2010). It is not surprising at all that this structure leaving so much traces in the city is designed for a museum. It has brought a radical innovation to cultural, sociological and, as it attracted a lot of tourists, economic structure of Paris. It is the first example showing how a museum may affect urban life (Ihtiyar 2011). Inspired by the success of that cultural centre, many European cities engaged in the construction of new museums and the expansion of existing ones such as Guggenheim Museum in Bilbao, new Tate Modern, the British Museum with its spectacular new glazed Great Court and the renovation of the Louvre in Paris (Aalst, Boogaarts 2002).

The "Bilbao effect" concept, which is used to represent the contribution of Frank Gehry's Guggenheim museum in Bilbao to the promotion of the city at international level and its power of transformation over the city, is still used in many areas (Fig. 3). This "reference building" introducing the city to the world and

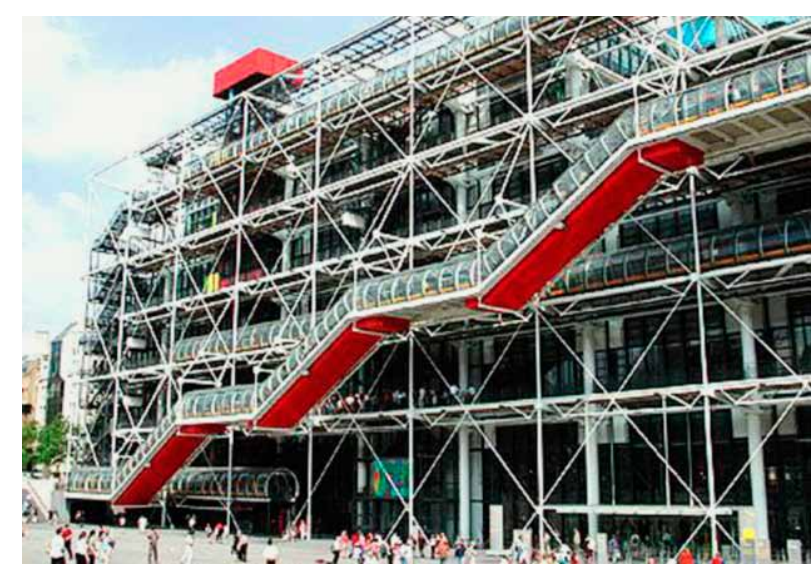

Fig. 2. Pompidou Center (photo by the authors)

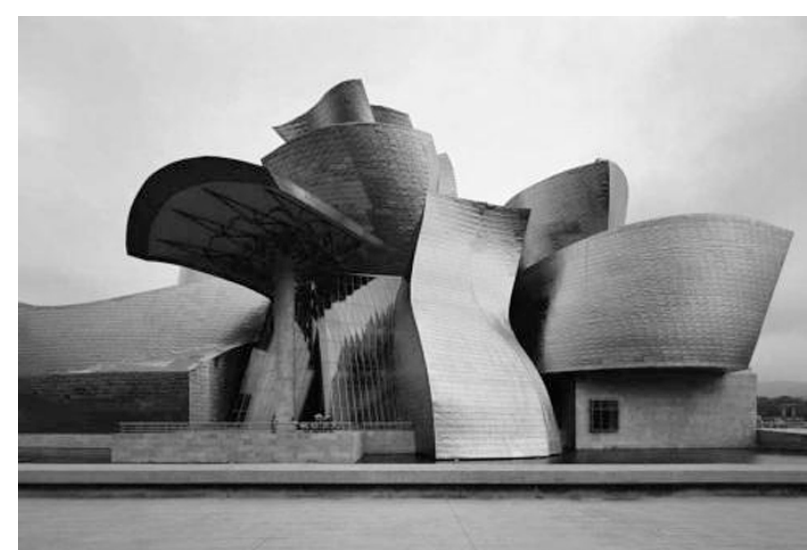

Fig. 3. Bilbao Guggenheim Museum (www.mimdap.org) keeping alive the economy by attracting millions of tourists to middle-class Bilbao has been a pioneer in the reconstruction of the city. That extraordinary project selected through a competition, has provided a new ideology and vision to the boring and serious face of the museum along with the effect of the technology (Zeiger 2005). According to Foster (2004), Museum, after its opening in October 1997, generated such a tremendous economic and cultural impact that, a strong demand has occurred in terms of today's architects to create such works around the world. This model of which middle-class cities are turned into a brand by iconisation of the buildings has been implemented in many cities later (Ihtiyar 2011). Because of the radical, dramatic and spectacular nature of the architecture of the museums such as Getty Museum in Los Angeles, Reina Sophia in Madrid, Stedelijk in Amsterdam they arguably function as tourist attractions in their own right in addition to the art they contain (Hamnett, Shoval 2003).

It is observed that the iconic cultural buildings can be seen as an effective alternative to using tourism in transformation of a city since the mid-20th century (Ihtiyar 2011). Yilmaz (2009) indicates that "once unknown cities have become the focus of interest and the tourism-fed capital with the introduction of bespoke "icon" buildings." He asserts that imagery to create collective memory as an urban need is being marketed today and an industry of "iconic architecture" have emerged to generate such an image. According to Köksal, the meaning of the envelope is becoming more important in terms of the museums especially due to its creation of iconic value in the city (Gökmen 2010).

Zukin (1998) states that cities are no longer seen as landscapes of production, but as landscapes of consumption. According to Harvey (1989) the city has to appear as an innovative, exciting, creative, and safe place to live or to visit, to play and consume in. Functioning at the intersection of art, culture and tourism, museums seem to have a great impact on the urban culture. Therefore what is the situation of Istanbul in this context? How do the museum buildings in Istanbul contribute to the image and tourism of the city?

\section{Image of Istanbul}

When it comes to Istanbul, the Bosporus comes to mind which joins the continents of Asia and Europe, makes two sides meet and has a different colored unique geography and topographic properties in each side. According to Mungan, Istanbul is a fundamental image and a metaphor. Mungan asks the following question while searching for the image of Istanbul 
"Istanbul is the archetype of Turkey's collective memory" (Mungan 2009). According to Köksal (2011), most of the cities in the world are remembered by the structures identified with the city, representing the city by itself and forming a sufficient image related to the city. Well, is there a structure representing alone Istanbul having more ancient history than these cities and having been the capital of the empires for centuries? There isn't such a structure according to Köksal; Süleymaniye Mosque of Sinan the Architect or Haghia Sophia that has been one of the most important structures of the world from the time it was built until today cannot embrace the image of Istanbul. However, Köksal says that Istanbul actually has a strong image and this image is the peninsula being the center of history in the city and its strong silhouette in the same article of him named "the Silhouette of Istanbul as an Image".

Istanbul can be classified as "historical-heritage city" according to Judd and Feinstein's (1999) classificsation. However, historical assets, the silhouette and geographical features of Istanbul are insufficient to make it the center of cultural tourism. For example, according to TURSAB (Association of Turkish Travel Agencies) data (Turkish Museums Report 2013), the number of historical ruins in Istanbul is two times more than that of London and ten times more than that of Paris. Nevertheless, the number of museums has a reverse situation. There are 7 national museums and 71 museums in the category of "other museums" in Istanbul. This number in London is approximately two times more than that of Istanbul, about 172 . Similarly, the number of museums in Paris and New York nearly doubles the number in Istanbul. There are 137 museums in Paris and 131 museums in New York. These numbers reveal that Istanbul is rich in historical heritage and it is at the bottom of the ladder in terms of preserving, turning into museums and presenting them (Table 1).

The museums have emerged as "a modern institution" indicative of Westernization efforts of the 19th century targeting the "protection" of the rich historical and cultural heritage in Turkey where museums and museum history is a recently developed issue (Özkasım,
Ögel 2005). The museum in efforts of the developing countries in the Eastern Europe to get closer to Western civilization has been tried to be implemented by mimicking the West, however the museum as a value in terms of diplomacy and tourism in these societies could not integrate with the public. The museums mimicking the 19th century Western museums at the time of their foundations have not been addressed afterwards and this order has continued until this day (Oruçoğlu 2002).There emerged a mentality of turning the official public buildings which have lost its original function especially in urban areas into museums (Madran 2009). It can be argued that Milojković and Nikolić consider this situation as an advantage. According to them; buildings that fail to be exciting cannot attract the masses. This explains why many museums, galleries and other cultural institutions are located in valuable historical buildings and recently in converted industrial buildings. These spaces have almost always fascinating dimensions. Although they are emblematic structures, there is not any fear that these buildings prevent art because the place of these buildings in the memory of the city has already been accepted (Milojković, Nikolić 2012).

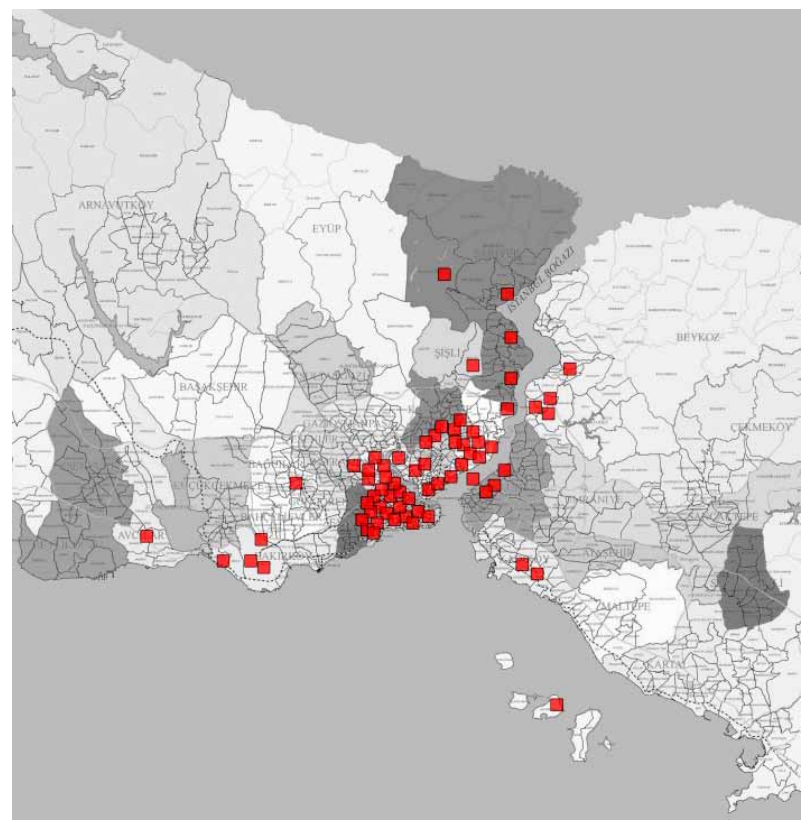

Fig. 4. Locations of the museums in Istanbul

Table 1. Comparison of the number of museums and visitors. (Turkish Museums Report 2013)

\begin{tabular}{c|c|c|c|c}
\hline & İstanbul & London & Paris & New York \\
\hline Number of national museums & 7 & 11 & 24 & 2 \\
\hline Number of other museums & 71 & 162 & 113 & 129 \\
\hline Most visited 5 museums/ number of visitors (million) & 7,1 & 25,3 & 23,4 & 15,4 \\
\hline
\end{tabular}


The museums of Istanbul, which is one of Turkey's most important cities in terms of historical, cultural and natural values, are the structures that are- to a great extent - formed through transformation of historical buildings. There are 78 large and small museums (Fig. 4) located in Istanbul (Museums in Istanbul 2015). In this study, the three museum buildings in Istanbul were chosen as an example. The first of the selected museums (the most visited museum in Turkey) is the Topkapi Palace Museum. This museum is one of the emblematic buildings mentioned by Milojković and Nikolić. Second one (Istanbul Museum of Modern Art) is the first modern art museum implemented in Istanbul and the third one is the first modern building designed as a museum in Istanbul. Naval museum building can be said to be an important step for museum architecture in Turkey. Indeed, new museum buildings have been obtained in other Turkish cities with the way of the competition.

\section{Method of the study}

Cities are made up of parts that interact/communicate with each other continuously. Changes in each of these components change themselves and their relationships with each other as well as city itself inevitably. For example, according to Güzer (2010) Zaha Hadid's Maxxi Museum of Contemporary Art in Rome (Fig. 5) or I. M. Pei's Museum of Islamic Art in Doha (Fig. 6)

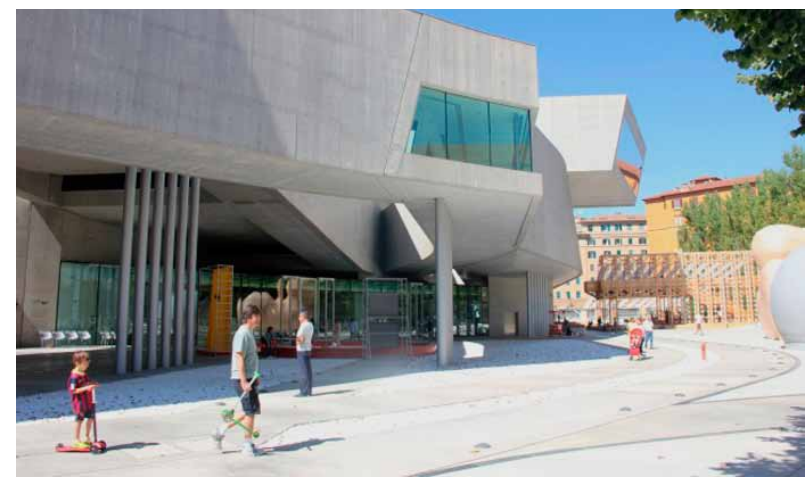

Fig. 5. Maxxi Museum (photo by the authors)

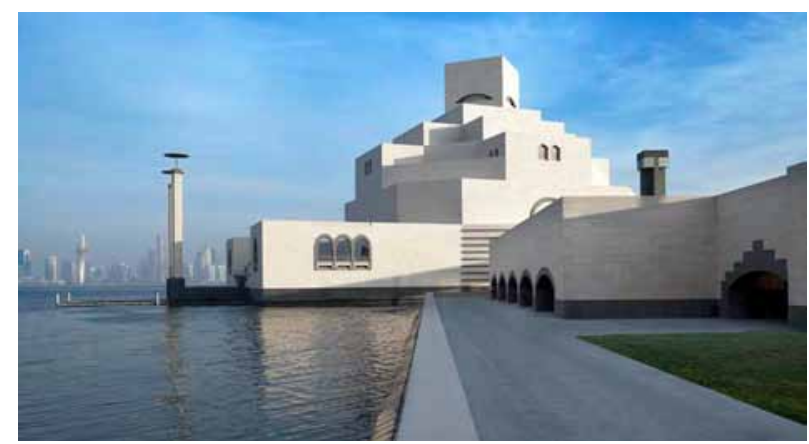

Fig. 6. Museum of Islamic Art in Doha (www.e-architect.co.uk) are perceived as urban focus and a point of attraction that transform their environment in a multi-dimensional way.

Actually, the city/ museum relationship includes a double-sided case as all other forms of relationships. It can be said that each side have an effect on each other in this relationship. For this reason, in this study, urban/museum relationship has been studied to understand in two separate axes in the context of image (the impact of the city on the museum, the impact of the museum on the city) and the dynamics of these axes. In the present study first the selected museums have been analyzed in terms of the city-museum interaction and have been evaluated within the context of the contributions they make to the image of Istanbul by descriptive methodology.

Undoubtedly, it is not possible to examine all the museums located in Istanbul within the scope of this article. Therefore; the method of examination by selecting the museums that are prominent with their quality in some fields is preferred. On the other hand, in our opinion, the matter of image is a bit vague that has different meanings depending on the viewer and therefore is so difficult to define clearly and thus an interesting matter full of differences. For this reason; instead of following a systematic approach to the assessment of this regard, the creation of a holistic view of outlook/ image by recording visual material and all the dynamics of this relationship onto a plane was preferred.

\section{Topkapi Palace Museum}

Built in 1478 by Mehmed the Conqueror, Topkapi Palace has been the center of State Administration and official residence of the Ottoman sultans around 380 years until the construction of Dolmabahce Palace by Abdulmecid (Fig. 7). Topkapi Palace has been evacuated as people begin to live in the Dolmabahce, Yildiz and other palaces. Topkapi Palace was opened to the public with the order of Gazi Mustafa Kemal Atatürk, on April 3, 1924 (Öztekin 2014), after undergoing repairs and visits by the sultan`s family from time to

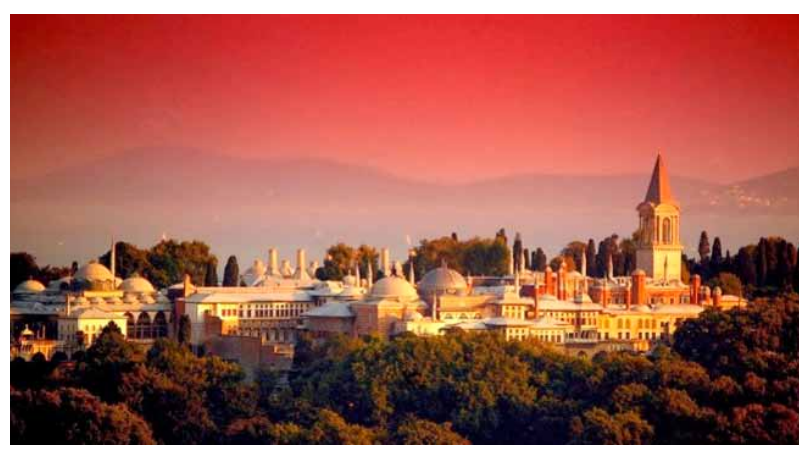

Fig. 7. Topkapi Palace Museum (www.mimdap.org) 
time. The Museum that hosts a rich collection and imperial treasures of the Ottoman Empire is also the first museum of the Republic.

\section{The effect of the city on the Museum}

Topkapi Palace was built on the historical Byzantine acropolis in Sarayburnu at the tip of the peninsula between the Sea of Marmara, the Bosporus and the Golden Horn. In this region, there are magnificent buildings such as the Blue Mosque, Hagia Sophia and Hagia Irene museums alongside the Topkapi Palace. In fact, the palace is a collection of buildings accumulated over time and surrounded by the gardens and squares (Fig. 8).

\section{The effect of Museum on the city}

Topkapi Palace Museum is the most visited (3,553,078 visitors in 2014) museum in Istanbul due to its collections as well as its place in Ottoman history.

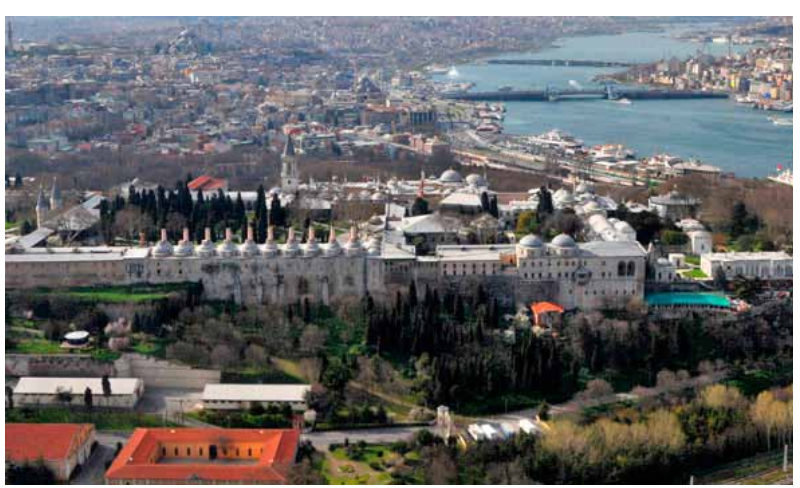

Fig. 8. Topkapi Palace Museum (www.mimdap.org)

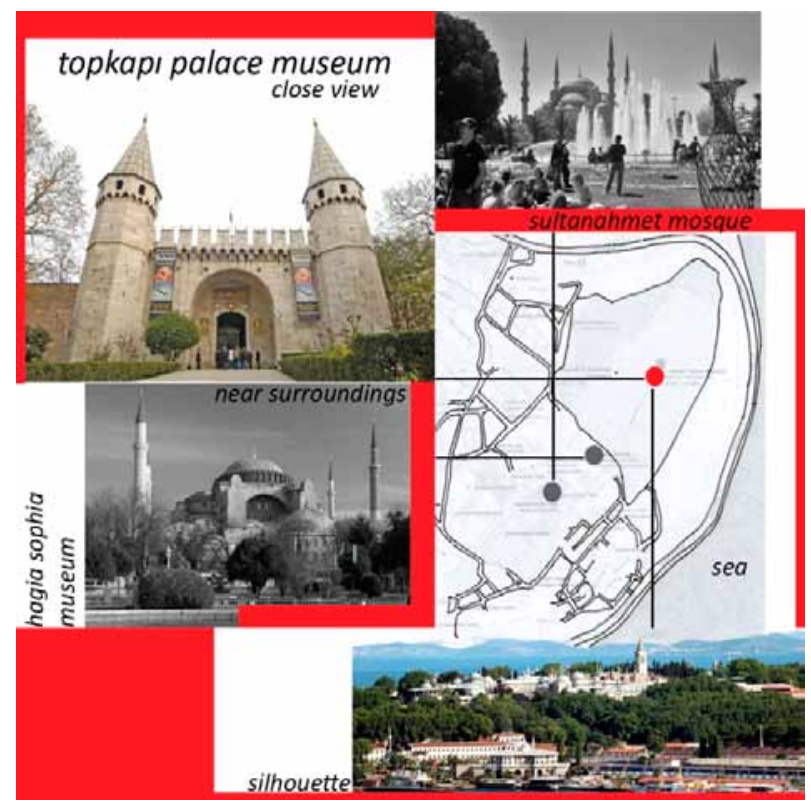

Fig. 9. Topkapi Palace Museum, collage by authors
Therefore, it affects its surroundings to a great degree as it creates a point of attraction. However, it cannot be said to be an important contribution to urban space outside the museum - except some special events to be included - due to the limitations imposed by the palace architecture and introverted spatial function. On the other hand, it is a determinant/dominant part of the silhouette from the sea. In Köksal's (2014) words, the palace has been transformed into almost a part of urban topography and a component both introducing and closing the Istanbul skyline. Moreover, the top meeting the sea when approaching the peninsula and the skyline of the Hagia Sophia, Suleymaniye and the Topkapi Palace creates an image to be remembered (Fig. 9).

\section{Istanbul Museum of Modern Art (Istanbul Modern)}

Istanbul Museum of Modern Art (Figs 10, 11) is Turkey's first and largest museum in the field contemporary art. On its website Istanbul Museum of Modern Art has been described as "a museum which houses interdisciplinary activities to share Turkey's artistic creativity with wide audiences and promoting its cultural identity in the international art world" (Eczacıbaşı 2015). The building was built as a warehouse during the reorganization of Tophane Square between the years 1957-58 under the management of the famous architect Sedad Hakki Eldem. The warehouse No. 4

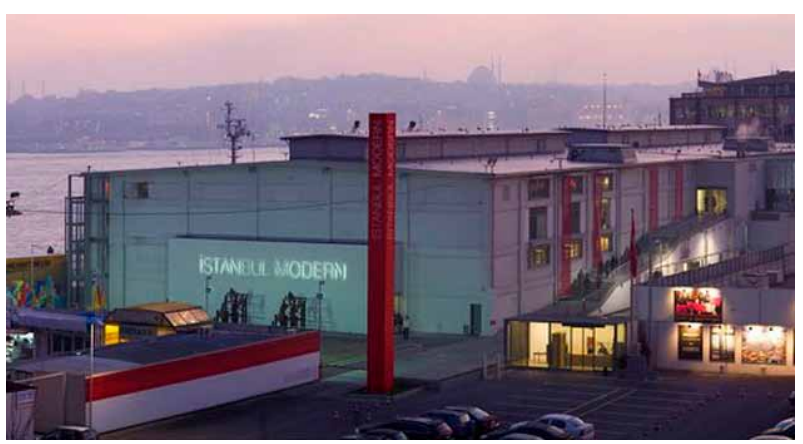

Fig. 10. Istanbul Museum of Modern Art (www.istanbulmodern.org)

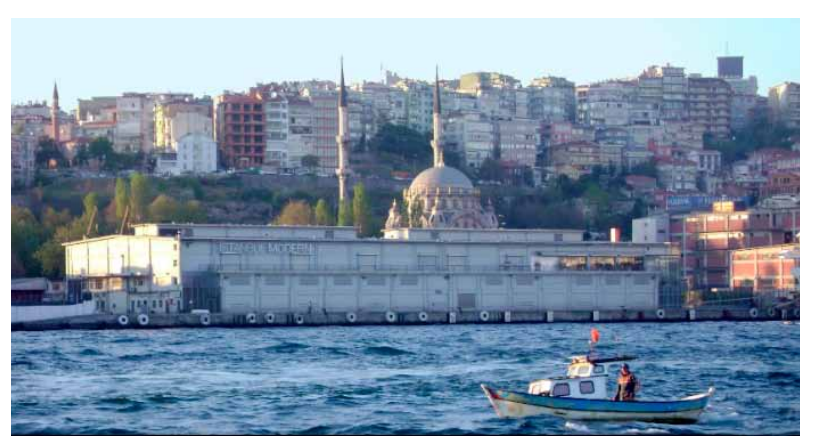

Fig. 11. Istanbul Museum of Modern Art (www.istanbulmodern.org) 
not used by the Maritime Businesses for a long time and waiting as redundant became a museum in 2004 after use at 8. Istanbul Biennial in 2003.

\section{The effect of the city on the Museum}

Istanbul Museum of Modern Art is located in the south of Bosporus on the coast of Karaköy and Tophane. Istanbul Modern is located on a major transportation hub due to its location. The museum located in front of the Karaköy Harbor for ships carrying international tourists and attracts many foreign tourists. Tophane-i Amire building planned to be used as Istanbul City Museum, Nuri Osmaniye Mosque, Kilic Ali Pasha Mosque as one of the important works of Mimar Sinan are located near the museum. The front of the Istanbul Museum of Modern Art embracing Marmara Sea is faced with Sarayburnu skyline which the Topkapi Palace is a part. This impressive view creates a reference on the coast line to associate museum with the city and its history and literally offers a panorama of Istanbul for visitors as a continuation of those exhibited (Fig. 12).

\section{The Effect of Museum on the City}

Istanbul Modern's vision is "to be a reference point in the global art world as a modern and contempo-

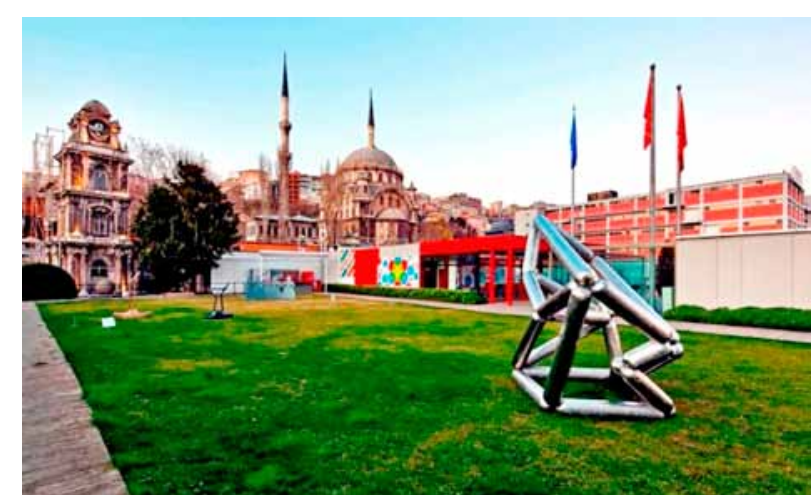

Fig. 12. Garden of Istanbul Museum of Modern Art (photo by the authors)

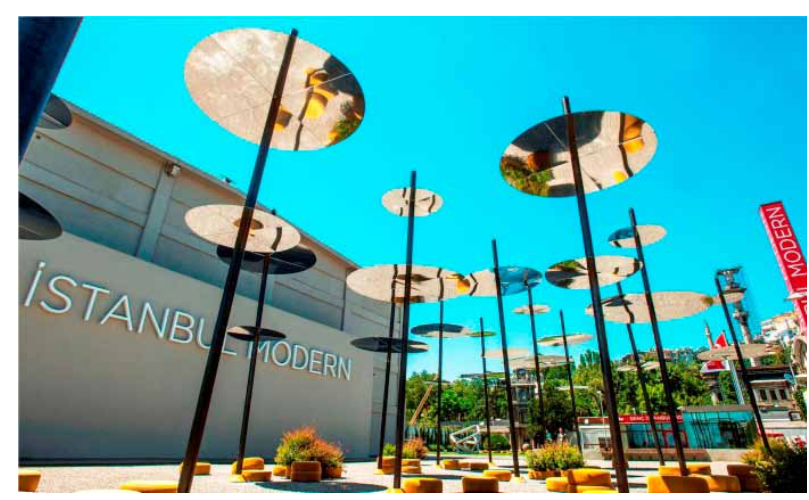

Fig. 13. Istanbul Museum of Modern Art, YAP installation (www.istanbulmodern.org) rary art museum". According to the Chairman Oya Eczacibaşı (2015) the Istanbul Modern Art Museum is advancing rapidly towards its objectives. "Istanbul Modern is now reaching out to broader segments of society through the activities and is gradually getting closer to accomplishing the original founding objectives." Istanbul Modern was cited as "the changing face of Turkey" in New York Times". On the other hand, museums' functions as a means of transformation in the general perception of museums in Turkey and offers a layout in which the audience evolve from a visitor to a participant by hosting child, youth programs, films and other meetings. In addition to the interior of the museum building, temporary installations in open areas increase the participation of this area into the city. For example, YAP Istanbul Modern (Fig. 13): New Architecture Program that Istanbul Modern started in 2012 with the cooperation of The Museum of Modern Art (MoMA) and MoMA PS1 gives an opportunity to young and rising architects to design a temporal structure in the garden of Istanbul Modern in every two years in summers. Whereas these structures dynamize the museum, they also make a modern contribution to the image of the city. Moreover, qualified temporal exhibitions, the restaurant above the Bosporus and sales unit increase the number of visitors $(630.000$ visitors in $2014-40 \%$ of foreign visitors) of the museum and create an important income.

Istanbul Museum of Modern Art is a powerful element of the city's skyline strengthening the dominant effect of the shoreline due to its horizontal character located in the city memory for a period of more than half a century (Fig. 14).

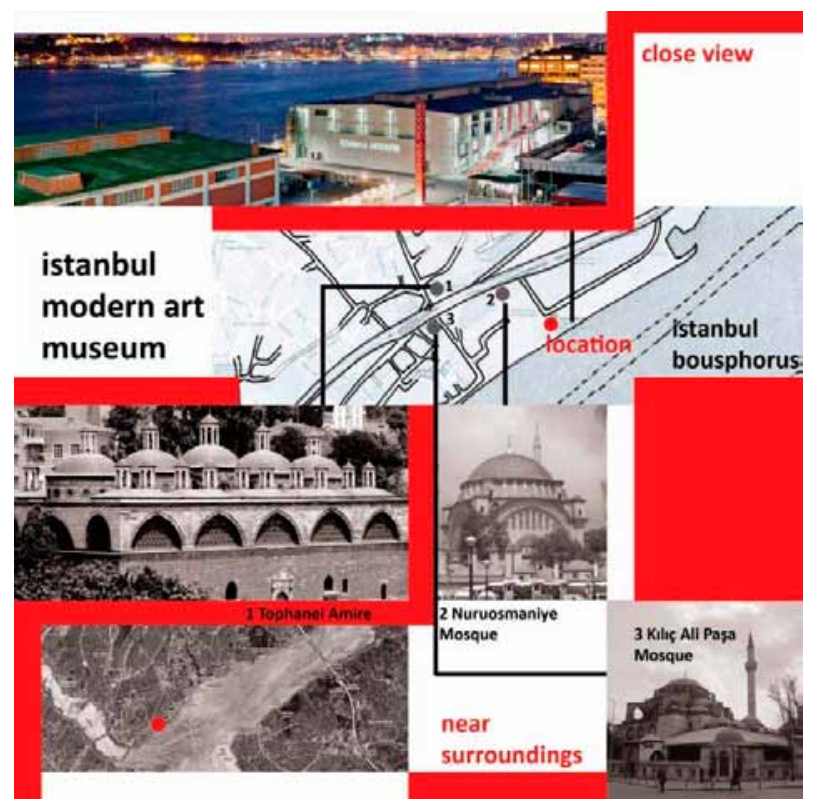

Fig. 14. Istanbul Museum of Modern Art, collage by authors 


\section{Istanbul Naval Museum}

Istanbul Naval Museum building is the first structure built for the museum function since Istanbul Archaeology Museum (1954) and one of its architects Ertug Ucar (2008) describes the museum as the first example of the modern museums designed for a historical collection in Istanbul (Figs 15, 16). In addition, another important feature of the building is to have the distinction of being the only public building made in recent years to the Bosporus (Fig. 19).

Museum project was obtained with a national architectural competition opened in 2005 and was opened to visitors in 2013. The architects stated in the competition report that "Naval Museum in Beşiktaş is a lost and forgotten complex in the center of Istanbul and proposed project puts this secluded area on the shores of the Bosporus to use."

\section{The effect of the city on the Museum}

As the building is on one of Istanbul's busiest straits settlements and the land stuck to the center of the settlement, this have led to a remodeling that gives life to its surrounding. According to Ucar (2008), the square created with a withdrawn from the plot line

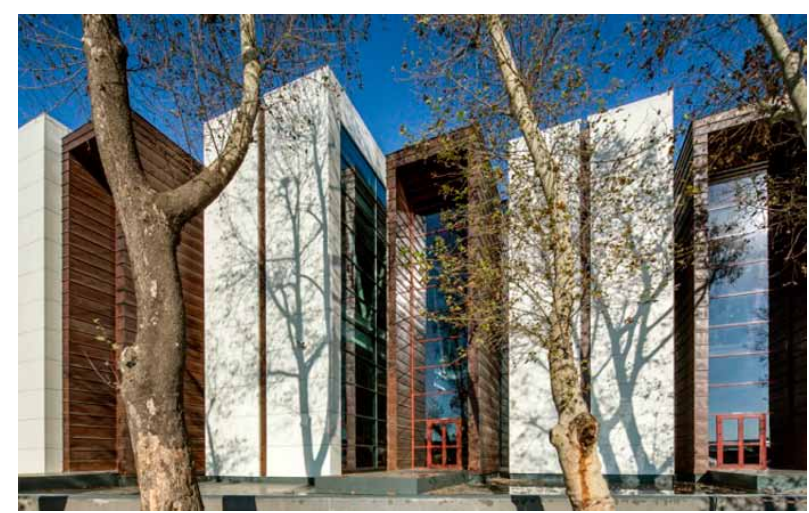

Fig. 15. Istanbul Naval Museum - view from seaside (www.arkitera.com)

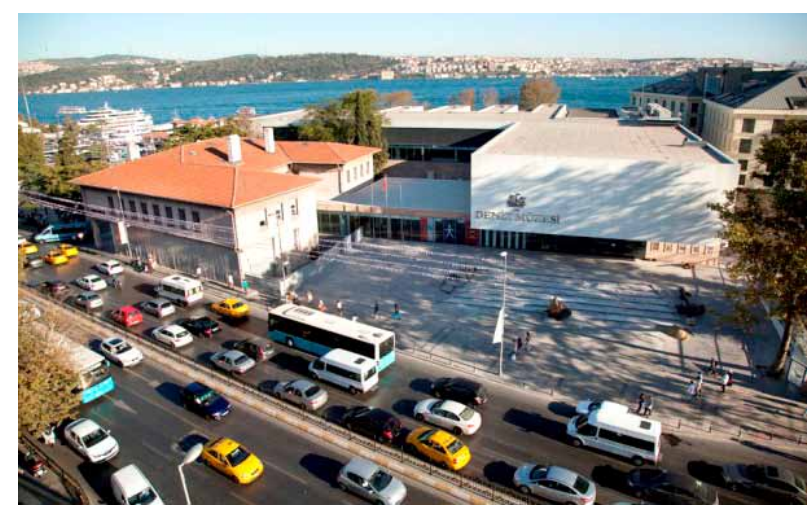

Fig. 16. Istanbul Naval Museum - general view (www.arkitera.com)

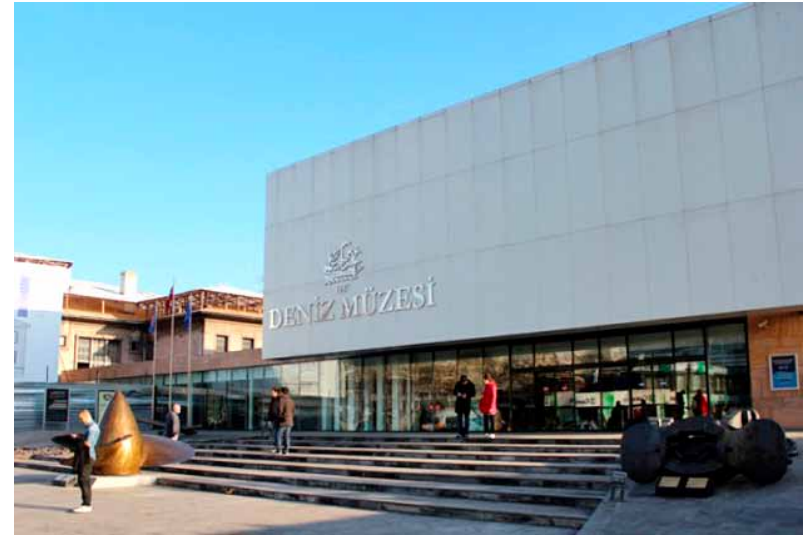

Fig. 17. Istanbul Naval Museum - entrance (www.arkitera.com)

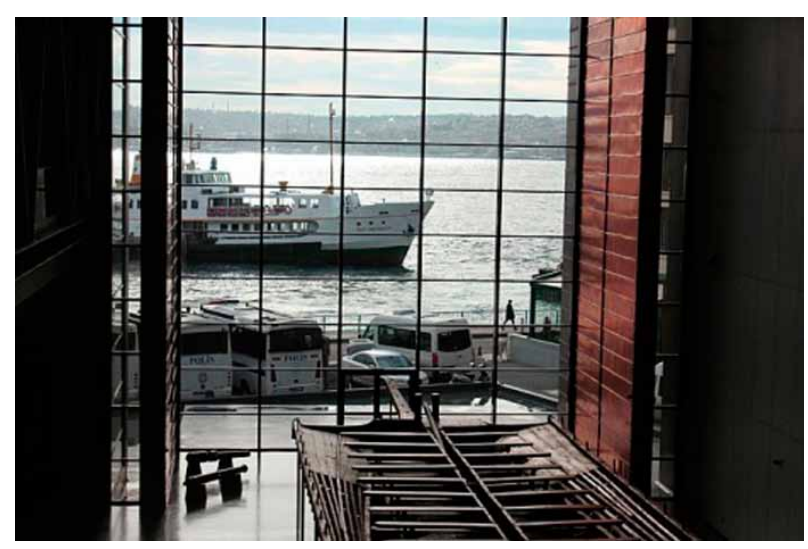

Fig. 18. Istanbul Naval Museum - interior (www.arkitera.com)

on the side of Dolmabahçe is a new meeting venue for people stuck to the pavement (Fig. 17). This area included in urban spaces as a gesture shows the museum's new social role. Building on the shores of the Bosphorus in the configuration significantly affects the state of being: "There is a large boathouse with sleds overlooking the Bosphorus. View of the Bosphorus from the museum is a dock: The end of the supply is made waiting for the opening a fleet"(Fig. 18).

\section{The effect of the Museum on the city}

This new building is conceived as associated with the existing building however does not interfere the old building and the city and on the contrary has made more visible by opening the front. Uçar (2008) states that Istanbul Naval Museum project reveals a model not only contributing to the perception of city on the axis of internal access but also to the skyline on the Bosporus-side and the view at the museum's urban space: "While the exhibition and circulation areas in the museum deal with the most important "qualities" of Besiktas center - Dolmabahce Palace, Besiktas Square, Iskele Street and Bosporus - visually and physically, "the right path for turning the congested 


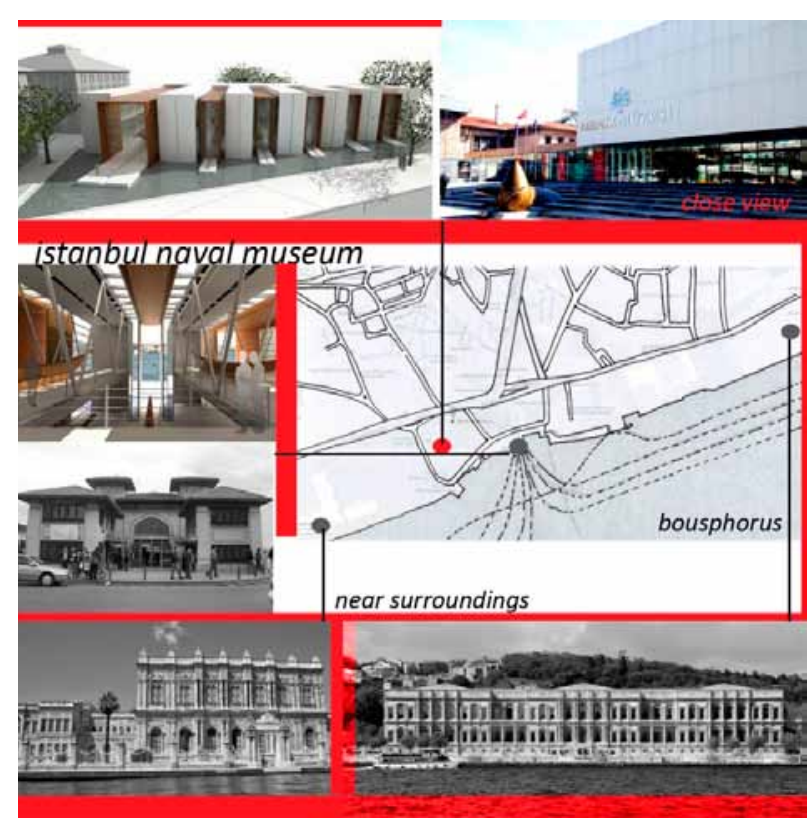

Fig. 19. Istanbul Naval Museum, collage by authors

territory into an advantage" for the museum as well as the city is being searched with the project."

It seems possible to say that the building does not appeal to the citizens and tourists sufficiently when the number of visitors (166704 visitors in 2014 - only $5 \%$ of foreign visitors) has been evaluated. The reasons why the significant collection does not arouse enough interest could be that it doesn't have a striking architecture although it is a very qualified building. Moreover the building cannot provide a union with urban space as envisaged in the design process. On the other hand, placing the cafe on Bosphorus side instead of the entrance side of the building could be an important source of income for the museum by attracting people. In fact the building allows for the functions (rent spaces, cafe, kids space, sale unit) expected from modern museum that could provide increasing the consumption but not at the desired level mostly becouse of being a component of Turkish Naval Forces.

\section{Conclusions}

Museums have a significant role in the competitions and development of cities. They contribute both to the economy of cities and to the renovation of them. Accordingly, as well as their content, their architecture and relations with cities gain importance. In this study, the important museums of Istanbul have been evaluated within the context of the contributions they make to the image of Istanbul. Some reviews have been made after the investigation connected to the citymuseum relations in the context of images through examples that appear very different from one another:
Naval Museum differs from 15th century Topkapi Palace and Istanbul Modern which was transformed from a bonded warehouse of $50 \mathrm{~s}$, as a contemporary structure designed as a museum. However, due to its location and the effect of the presence of the palace structures along the coast while on the one hand it expresses its own unique entity on the other hand it can be said that it chose to be a part of historical heritage. It can be asserted that this museum which is the first one designed in Bosporus shore could make a stronger contribution to the image of Istanbul with a striking architecture rather than preferring a quiet one and thus it can be made the center of interest. All three museums are an important attraction for the city and its vicinity as well as attraction centers. However the naval museum has created a meeting point owing to the open space generated by pulling back the building on the road. This space both has opened the way for the existing building and has created an open-focus by forming a square. All three museums play an important role in the city's skyline. At this point, the Topkapi Palace Museum offers a powerful image in Istanbul with its location and topography as well as the influence of other icon buildings/ focal points located around. The unique silhouette of Sarayburnu brings İstanbul to the minds of people from all over the world. Istanbul Museum of Modern Art offers modern art to the city in the 60 years warehouse buildings and just like the Naval Museum has turned the silhouette of the Anatolian side of Istanbul into a part of the exhibition. In fact, it is a modest building for a museum but especially the installations performed in the garden of Istanbul Modern every other year can be considered as an effort of the museum to communicate with the city.

On the other hand, it is pleasing that two museums will be realized in Istanbul. One of them is modern arts museum designed by Kirsten Leens and will be done in Dolapdere and the other one is the museum designed by Zaha Hadid and will be done in Sütlüce. Designed by two significant architects, these buildings are expected to make contributions to cultural tourism and image of Istanbul. Istanbul should not take on a historical city image by only preserving its past and historical values, but it should be open to the investment of contemporary cultural buildings that have potentials to reinforce city's image.

Although the city/museum relationship in the context of the image has been assessed in two axes in this study (the city's effect on museums, the museum's effect on the city), it has been observed as a result of the surveys that these two axes may have separate or spiral relationship from time to time. This complex 
relationship reproduces itself endlessly with the city's ever-changing nature. But it seems possible to call this relation as a "symbiosis" since promoting the image of the city by the help of museum buildings will bring an improvement on its power in competition between cities, which in turn will attract more visitors to the museum again.

\section{References}

Aalst, I.; Boogaarts, I. 2002. From museum to mass entertainment the evolution of the role of museums in cities, European Urban and Regional Studies 9(3): 195-209. London: SAGE Publications. http://dx.doi. org/10.1177/096977640200900301

Bilbao Guggenheim Museum [online], [cited 2 January 2015]. Available from Internet: http://www.mimdap.org/? $\mathrm{p}=12377$

Eczacıbaşı, O. About [online], [cited 10 January 2015]. Available from Internet: http://www.istanbulmodern.org/en/museum/about_760.html

Foster, H. 2004. Tasarım ve Suç [Design and Crime]. Istanbul: İletisim Publications. (in Turkish)

Gökmen, H. 2010. (Aykut Köksal ile röpörtaj) Müze ve Mimarlığı Üzerine (Interview with Aykut Köksal on Museum and its Architecture), Ege Mimarlik 74: 22-27

Güzer, A. 2010. İtibarını Geri İsteyen Bir Yapı Olarak Müze, Ege Mimarlk 74: 14-15.

Hamnett, C.; Shoval, N. 2003. Museums as 'flagships' of urban development, in L. M. Hoffman, D. Judd, and S. S. Fainstein (eds.). Cities and visitors: regulating people, markets, and city space. Oxford: Blackwell. http://dx.doi. org/10.1002/9780470773673.ch12

Harvey, D. 1989. From managerialism to entreprenurialism: the transformation in urban governance, Geographiska Annaler 71(1): 3-17. http://dx.doi.org/10.2307/490503

Ihtiyar, M. N. 2011. Çağdaş Müzecilik ve Kent Müzeciliği Yeni Bir Program Önerisi [Contemporary museums and city museums: a new approach for the city museum]: Unpublished Master Thesis, ITU Institute of Applied Sciences, İstanbul. (in Turkish).

Istanbul Museum of Modern Art, YAP installation [online], [cited 03 February 2015]. Available from Internet: http://www. istanbulmodern.org/en/press/press-releases/sky-spottingstop_1213.html

Istanbul Naval Museum [online], [cited 21 February 2015]. Available from Internet: http://www.arkitera.com/ proje/2784/http---arkivcomtr-proje-istanbul-denizmuzesi-2784

Jencks, C. 2005. The iconic building: the power of enigma. Frances Lincoln.

Judd, D.; Feinstein, S. 1999. The tourist city. Yale: Yale University Press.

Köksal, A. 2014. Bir İmge Olarak İstanbul'un Silüeti [Silhouette of Istanbul as an image], [online], [cited 30 September 2014]. Available from Internet: www.arkitera.com . (in Turkish)

Madran, B. 2009. Müze, in P. Derviş, B.Tanju, U.Tanyeli (eds.). İstanbullaşmak, Olgular, Sorunsallar, Metaforlar [Becoming Istanbul, Facts, Problematics, Metaphors]. Istanbul: Garanti Gallery. (in Turkish)
Milojković, A.; Nikolić, M. 2012. Museum architecture and conversion: from paradigm to institutionalization of ant1-museum, Architecture and Civil Engineering, Facta Universitatis 10(1): 69-83.

Mungan, M. 2009. Istanbul İmgeleri [online], [cited 09.08.2014]. Available from Internet: http://www.obarsiv.com/pdf/murathanmungan.pdf

Museums in Istanbul. 2015. [online], [cited 15 January 2015]. Available from Internet: http://istanbul.gov.tr/Default. aspx?pid=14233 (in Turkish)

Museum of Islamic Art in Doha [cited 2 January2015]. Available from Internet: http://www.e-architect.co.uk/images/jpgs/ qatar/museum_islamic_art_imp081208_5.jpg

New York Guggenheim Museum [cited 2 January 2015]. Available from Internet: http://www.bc.edu/bc_org/avp/ cas/fnart/fa267/FLW_guggenheim.html

Oruçoğlu Z. 2002. Toplumsal Uyum Merkezi Olarak Müzeler [Museums as Social Cohesion Centers], in Sanat ve Sosyal Adanmışlık SANART 5. International Sympossium, 01-03 May, 2012, ODTÜ/Ankara, Turkey (in Turkish)

Özkasım, H.; Ögel, S. 2005. Türkiye'de Müzeciliğin Gelişimi [Development of Museology in Turkey], itü dergisi/b 2(1): 96-102. (in Turkish)

Öztekin, O. A. 2014. Müze Kavramı ve Müze Yapılarının İç Mekanlarının İstanbul'dan Örneklerle İncelenmesi [Analyze of the museum concept and interiors of museum buildings with examples from Istanbul]: Unpublished Master Thesis, Haliç University Institute of Applied Sciences, İstanbul. (in Turkish)

Topkapi Palace Museum [online], [cited 14 February2015]. Available from Internet: http://www.mimdap.org/?p=35457

Turkish Museums Report. 2013 [online], [cited 10 May 2015]. Available from Internet: http://www.tursab.org. tr/dosya/12194/tursab-turkiye-muzeleri-2013-raporu_12194_5662488.pdf

Uçar, E. 2008 Boğaz İle Kent Arasında Müze: İstanbul Deniz Müzesi [Museum between the Bosphorus and the city: Istanbul Naval Museum], Arredamento Mimarlık 216: 85-88. (in Turkish)

Zeiger, M. 2005. New museum architecture. London: Thames \& Hudson.

Zukin, S. 1998. Urban lifestyles: diversity and standardisation in spaces of consumption, Urban Studies 35(5-6): 825-39. http://dx.doi.org/10.1080/0042098984574

Yılmaz, A. 2009. İkonik Bellek Mimarlığı: İmge Olarak Yapı, Anı Olarak Mekan [The Architecture of Iconic Memory: Building as Image, Space as Memory], Mimar.ist 33: 62-67. (in Turkish)

\section{ILKER FATIH OZORHON}

Faculty of Architecture and Design, Ozyegin University, Çekmeköy Campus Nişantepe District, Orman Street, 34794 Çekmeköy,

Turkey.E-mail: ilker.ozorhon@ozyegin.edu.tr

Dr Ilker Fatih Ozorhon graduated from Yildız Technical University, Faculty of Architecture in 2000. He got the master degree from Istanbul Technical University by his thesis on

"Natural Light with Its Aspect Determining the Identity of Architectural Space" at Architectural Design Program in 2002. 
He completed his PhD studies at Istanbul Technical University, Architectural Design Program by his thesis named "The Issue of Originality in Architecture: Turkish Modernity in the period of 1950-1960" in 2008. He has studies published in several journals, presented in symposiums and congress and has awards in architectural design competitions. He is working as an Assistant Professor at the Faculty of Architecture and Design in Ozyegin University. His recent research areas include Architectural Design, Design Teaching, Modernity and Modern Architecture, Modern Turkish Architecture.

\section{GULIZ OZORHON}

Faculty of Architecture and Design, Ozyegin University, Çekmeköy Campus Nişantepe District, Orman Street, 34794 Çekmeköy, Turkey.E-mail: guliz.ozorhon@ozyegin.edu.tr

Dr Guliz Ozorhon, graduated from Yıldız Technical University, Faculty of Architecture in 2000. She obtained the master degree from Mimar Sinan University of Fine Arts. She completed her PhD studies at Yıldız Technical University, Architectural Design Program by her thesis named "Housing Architecture of Istanbul in the Period of 1950-1960" between 2003-2009. She has studies published in several journals, presented in symposiums and congress and has awards in architectural design competitions. She is working as an Assistant Professor at the Faculty of Architecture and Design in Ozyegin University. Her recent research areas include Architectural Design, Spatial Organization, Sustainability, Ecological Design, Housing-Housing Settlements, Architectural Education. 